
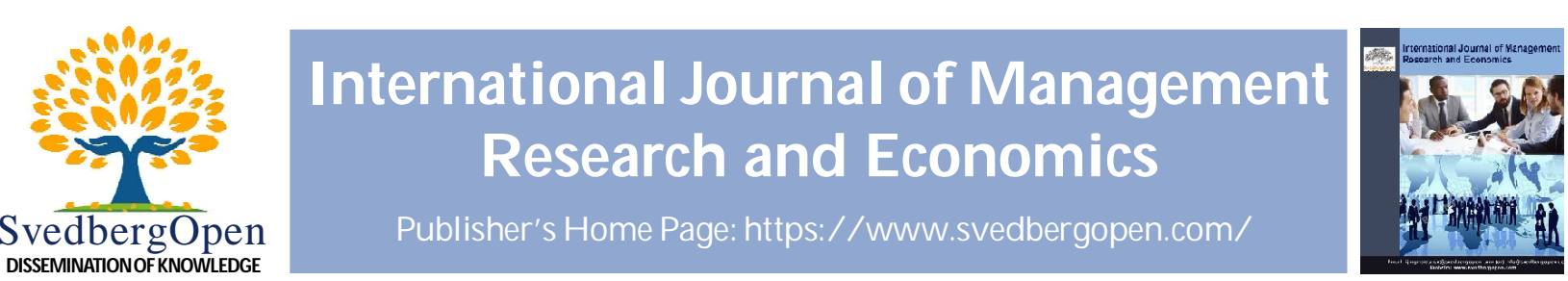

\title{
On Joan Robinson's role in creating the myth that R. Kahn originated the multiplier concept
}

\author{
Michael Emmett Brady ${ }^{1 *}$ \\ ${ }^{1}$ Adjunct Lecturer, California State University, Dominguez Hills, College of Business Administration and Public Policy Department of \\ Operations Management, 1000 East Victoria St., Carson, California 90747 USA. E-mail: mandmbrady@juno.com
}

\section{Article Info}

Volume 1, Issue 2, April 2021

Received : 13 December 2020

Accepted : 17 March 2021

Published : 05 April 2021

doi: 10.51483/IJMRE.1.1.2021.33-37

\begin{abstract}
An enduring myth accepted by all Orthodox and heterodox economists is that it was Richard Kahn who discovered and originated the concept of the multiplier. Kahn then supposedly showed Keynes how the multiplier concept could be specified mathematically so as to provide hard support for Keynes's views in the late 1920s about increased initial government spending on public infrastructure generating much larger increases in total spending than the original injection, leading to decreasing levels of unemployment. There are three major problems with this story. First, Kahn, himself, in a 1936 response to Hans Neisser in the Review of Economics and Statistics stated that most of his ideas about the multiplier concept came from Keynes. Second, the mathematical and logical development of the multiplier concept had already been formalized and formulated precisely by Keynes in 1921 on p. 315 in footnote 1 of the A Treatise on Probability in section 8 of chapter 26. Third, Keynes provided an arithmetic example of the mathematical technique worked out in the A Treatise on Probability in May, 1929 (Kent, 2007). There is simply no foundation for the myth, promoted by Joan Robinson, that Kahn was the author of the multiplier concept. Kahn went along with Robinson because he was involved in a 54-year old relationship with Joan Robinson. Keynes taught Kahn the theory of the multiplier concept and left it up to Kahn to write a full blown article on it, which was then published by Keynes in the June,1931 issue of the Economic Journal.
\end{abstract}

Keywords: Multiplier, Infinite series, Finite limit, Geometrical series, Decreasing series, Neisser, A Treatise on Probability, General theory

(C) 2021 International Journal of Management Research and Economics. This is an open access article under the CC BY license (https://creativecommons.org/licenses/by/4.0/), which permits unrestricted

use, distribution, and reproduction in any medium, provided you give appropriate credit to the original author(s) and the source, provide a link to the Creative Commons license, and indicate if changes were made.

\section{Introduction}

J M Keynes had already completely developed the technical, mathematical and logical framework of analysis for the concept of the multiplier in his A Treatise on Probability in 1921 long before Richard Kahn came to Cambridge in 1927 at the age of 22. However, Keynes did not have the time or inclination to actually publish a full blown, academic article giving a completely worked out arithmetic application of the mathematical theory of the multiplier in the EJ Keynes delegated this task to Kahn. Kent (2007) demonstrated that in May, 1929, Keynes had applied his logical theory of the multiplier in preparation for a speech in which he would take on all comers who questioned the concept of the multiplier. Kent showed that Keynes had made an arithmetic error in his arithmetic example of the mathematical theory of the multiplier.

\footnotetext{
* Corresponding author: Michael Emmett Brady, Adjunct Lecturer, California State University, Dominguez Hills, College of Business Administration and Public Policy Department of Operations Management, 1000 East Victoria St., Carson, California 90747 USA. E-mail: mandmbrady@juno.com
} 
Keynes privately showed Kahn sometime between May, 1929 and June 1931 that every application of the multiplier involved the mathematical theory in the A Treatise on Probability in 1921. Kahn's multiplier analysis on p. 183 of his June, 1931 EJ article is identical, except for notation, to Keynes's example from the A Treatise on Probability. One need only substitute Kahn's k on page 183 for Keynes's q on p. 315 to get the exact, same answer arrived at by Kahn.

Kahn's employment multiplier, k, is not a basic or major theoretical contribution to the General Theory. Keynes's discussion of the logical theory of the multiplier on pp.122-123 of the General Theory is a summary that is based on Keynes's p.315 analysis in the A Treatise on Probability from 1921. Therefore, Schumpeter's assessment that “...Mr. R. F. Kahn, whose share in the historic achievement cannot have fallen very short of co-authorship!” (Trevithick, 1994; Samuelson 1963; Schumpeter, 1954), has no support.

\section{Technical developments published by Keynes in 1921}

In the A Treatise on Probability in 1921 Keynes presents the following technical analysis in his footnote. He expects the reader to be able to deploy correctly that part of the differential calculus that deals with taking the limits of different kinds of series. Economists, like R. Hawtrey, D. Robertson (1936), and J. Robinson (1972), who either lacked such knowledge of calculus or had forgotten how to apply it, would not be able to grasp what Keynes was doing. Keynes addressed these economists on pp. 122-123 of the GT to point out to them that there was a difference between the concept of logical time deployed mathematically and actual, historical time.

\subsection{Consider Keynes's analysis on page 315 of the TP}

The 'risk' may be defined in some such way as follows. If $A$ is the amount of good which may result, $p$ its probability ( $p$ $+q=1)$, and $E$ the value of the 'mathematical expectation,' so that $E=p A$, then the 'risk' is $R$, where $R=p(A-E)=p(1$ $-p) A=p q A=q E$. This may be put in another way: $E$ measures the net immediate sacrifice which should be made in the hope of obtaining $A ; q$ is the probability that this sacrifice will be made in vain; so that $q E$ is the 'risk.' *

“*The theory of Risiko is briefly dealt with by Czuber, Wahrscheinlichkeitsrechnung, vol. i. pp. 219 et seq. If $\mathrm{R}$ measures the first insurance, this leads to a Risiko of the second order, $R 1=q R=q_{2} E$. This again may be insured against, and by a sufficient number of such reinsurances the risk can be completely shifted:

$E+R_{1}+R_{2}+\ldots=E\left(1+q+q_{2}+\ldots\right)=E /(1-q)=E / p=A . ”($ Keynes, 1921$)$.

Keynes expects a mathematically trained and literate reader to recognize that, because $p$ and $q(=1-p)$ are fractions, the terms $q, q_{2}, q_{3}$,etc. are declining. The ... dots mean that it is an infinite series. The problem is a geometric series, not an arithmetic series.

Keynes has taken the limit of a declining, geometric, infinite series to obtain $1 /(1-q)$ or $1 / p .1 /(1-q)$ or $1 / p$ is the Multiplier. The Multiplicand is $E$. We will see that Keynes's GT Investment Multiplier is mathematically, logically and technically identical to the TPMultiplier.

Paul Samuelson missed a golden opportunity to write the final chapter of the history of the multiplier in 1977 in his article in the Journal of Economic Literature. One of the sections in his 1977 paper dealing with the St. Petersburgh paradox considered Keynes's risk model, R. Samuelson studied page 315 of the TP when examining Keynes's Risk model. Samuelson, alone among economists up until the late 1970s, was the only economist to take Keynes's R model seriously. Unfortunately, Samuelson overlooked the first footnote at the bottom on page 315, where Keynes demonstrated the process of taking the limit of a geometrical, declining, infinite series led to a finite answer. Keynes's answer in the footnote on page 315 of the TP is identical to the answer given in the General Theory once $p+q=1$, where $p$ is the probability of success and $q$ is the probability of failure, is replaced by $m p c+m p s=1$, where $m p c$ is the marginal propensity to consume and mps is the marginal propensity to save.

It is very simple to connect the 1921 TP analysis to Keynes's GT analysis. Keynes states the following on p. 115 of the GT:

"Our normal psychological law that, when the real income of the community increases or decreases, its consumption will increase or decrease but not so fast, can, therefore, be translated—not, indeed, with absolute accuracy but subject to qualifications which are obvious and can easily be stated in a formally complete fashion into the propositions that $\Delta C_{w}$ and $\Delta Y_{w}$ have the same sign, but $\Delta Y_{w}>\Delta C_{w}$, where $C_{w}$ is the consumption in terms of wage-units. This is merely a repetition of the proposition already established in Chapter 3 above. Let us define, then, $\mathrm{d} C_{w} / \mathrm{d} Y_{w}$ as the marginal propensity to consume (Author's note-Keynes introduces the differential calculus into the problem at this point).

This quantity is of considerable importance, because it tells us how the next increment of output will have to be divided between consumption and investment. For $\Delta Y_{w}=\Delta C_{w}+\Delta I_{w}$, where $C_{w}$ and $I_{w}$ are the increments of consumption and investment; so that we can write $\Delta Y=k / \Delta I$, where $1-(1 / k)$ is equal to the marginal propensity to consume. 
Let us call $k$ the investment multiplier. It tells us that, when there is an increment of aggregate investment, income will increase by an amount which is $\mathrm{k}$ times the increment of investment" (Keynes, 1936).

However, Keynes realized that his mathematical approach specifying an investment multiplier was not understood by most economists. Therefore, he appended the following explanation on pp. 122-123 of the GT:

"In general, however, we have to take account of the case where the initiative comes from an increase in the output of the capital-goods industries which was not fully foreseen. It is obvious that an initiative of this description only produces its full effect on employment over a period of time. I have found, however, in discussion that this obvious fact often gives rise to some confusion between the logical theory of the multiplier, which holds good continuously, without time-lag, at all moments of time, and the consequences of an expansion in the capital goods industries which take gradual effect, subject to time-lag and only after an interval'(Keynes, 1936).

It is a simple task to apply Keynes's explanation on pp.122-123 of the GT in 1936 to the TP problem of 1921:

" $E+R_{1}+R_{2}+\ldots=E\left(1+q+q_{2}+\ldots\right)=E /(1-q)=E / p=A$."

Keynes's analysis (Keynes, 1921) holds good continuously, without time-lag, at all moments of time. However, the actual, real world process of shifting the risk through insurance in the financial markets takes "...gradual effect, subject to time-lag and only after an interval."

It is a simple matter to insert Keynes's $m p c=1-(1 / k)$ into the standard textbook representation of the investment multiplier as $M=1 /(1-b)=1 /(1-m p c)$ to obtain $1 /[1-(1-(1 / k]=1 /(1 / k)=k=$ “. ..the investment multiplier", where $m p c$ equals the marginal propensity to consume in the standard textbook representation.

Keynes's investment multiplier, where $I$ equals investment spending, is $I /(1-b)=I /(1-m p c)=I /(m p s)$, since, given $0<m p c, m p s<1$ and $m p c+m p s=1$. This is mathematically identical to the $1 /(1-q)$, since $p+q=1$ and $0<p, q<1$.

In conclusion, the mathematics of Keynes's exposition of the multiplier in the GT is identical to the exposition contained in the TP in 1921. Keynes's approach in the GT is the same as was done in the TP. He assumes that the reader of the GT has the mathematical training to recognize that the analysis given in chapter 10 is based on the calculus and involves an infinite, geometric series of terms that are declining.

\section{Post Keynesian acceptance of the Kahn myth}

"A sparse writer, Richard F Kahn renown nonetheless rests on a fundamental idea he formulated at the age of 25 and published in 1931 — which was duly pinched by his master, John Maynard Keynes, and made the centerpiece of the latter's General Theory (1936): the concept of the "multiplier". Kahn, nonetheless, bore his mentor no grudge and instead rose to be one of the leading figures of the Cambridge Keynesians. His colleague and close collaborator, Joan Robinson, was more willing than Keynes to credit him for his intellectual inspiration.”(Fonseca, G.L. (n.d.). History of Economic Thought. Institute for New Economic Thinking).

The boldfaced material is simply nonsense. It is impossible to argue that Keynes "pinched "Kahn's original work, or that he discovered "... a fundamental idea he formulated at the age of 25 and published in 1931...", because Keynes was the originator of the concept, not Kahn. Moreover, Kahn completely acknowledged this in a comment made to Neisser in (1936).

Keynes bent over backward to acknowledge Kahn's contribution to the use and application of the concept,but it was impossible for Keynes to attribute to Kahn the discovery of the logical and mathematical theory of the multiplier because Keynes had already done so 10 years before when Kahn was 16 years old.

\section{The myths of Joan Robinson live on}

Keynes helped Kahn to understand the mathematical and logical theory of the multiplier. That is why Kahn told Hans Neisser in (1936) that his ideas on the multiplier largely came from Mr. Keynes. After Keynes's death, Joan Robinson and G L S Shackle attempted to rewrite the history books so that it appeared that Kahn had independently invented and developed the multiplier. This is simply science fiction.

It was Joan Robinson who attempted to further develop the dubious perspective taken by Shackle in (1951) and claim that Kahn had somehow persuaded Keynes after working out the theory of the multiplier by himself:

"Keynes started life as a monetary economist. When he was working on his Treatise on Money, he thought that he had to be concerned strictly with the general price level. He rejected the suggestion that his subject was connected with the problem of unemployment. But in 1929 he had descended from this high theoretical plane to practical policy, 
supporting Lloyd George's campaign for public works. The pamphlet which he wrote with Hubert Henderson, Can Lloyd George Do It?, sketches out the theory that investment generates saving, so that a budget deficit can reduce unemployment without generating inflation. The analysis is very sketchy. R. F. Kahn took it up, worked out the theory of the multiplier in a more coherent manner, and persuaded Keynes that he and Henderson had been perfectly right. The ink was not dry on the first copies of the Treatise before Keynes began to acknowledge that employment was after all the central point."(Robinson, 1972, pp.2-3).

The boldfaced material is complete nonsense which was not challenged by any attendees when Robinson presented the paper as a speech at the 1972 AEA meeting. Robinson has her history upside down. Kahn never "persuaded Keynes". It was Keynes who showed Kahn what to do so that he could write his article and gain academic recognition from it.

\section{Conclusion}

Fonseca's article is simply based on a myth concocted by Joan Robinson with which Kahn went along with, as did A Robinson. It is similar to her myth about Keynes's 'instantaneous multiplier' being fallacious or to her myth that there is no IS-LM mathematical model in the GT. It is quite disconcerting to realize how many of Joan Robinson's myths are believed by economists in the year 2020. See Arthmar and Brady (2007); Brady (1997); Brady (2004); Chiang(1974); Kahn(1984); Keynes (1973); Keynes (1964); and Keynes (1979) for additional evidence supporting Keynes's clear priority over Kahn as regards the mathematical and logical development of the multiplier used in the General Theory.

\section{References}

Arthmar, R. and Brady, Michael Emmett. (2007). A 1929 Application of Multiplier Analysis by Keynes: a note. Unpublished; (November). Paper was rejected by the editor of History of Political Economy, Craufurd Goodwin, without review.

Brady, M.E. (1997). The Development of Keynes's Theories of Risk in chapters 26 and 29 of the A Treatise on Probability, 26, 143-145.

Brady, Michael Emmett. (2004). A Note on the Mathematics of the Keynesian Expenditure Multiplier and Keynes's Risk Model R of the A Treatise on Probability (1921). In Brady, M.E., Essays on John Maynard Keynes and .....Xlibris Press; Philidelphia, Pennsylvania, 500-504.

Chaing, A. (1974). Fundamental Methods of Mathematical Economics. (2nd edition). New York; McGraw Hill.

Fonseca, G.L. (n.d.). Richard F. Kahn, 1905-1989. History of Economic Thought. Institute for New Economic Thinking.

Kahn, Richard. (1931). The Relation of Home Investment to Unemployment. Economic Journal, 41, 173-98.

Kahn, Richard (1936). Dr. Neisser on Secondary Employment: A Note. Review of Economics and Statistics,18(3), 144-147.

Kahn, Richard. (1984). The Making of Keynes' General Theory. Cambridge: Cambridge University Press.

Kent, R. (2007). A 1929 Application of Multiplier Analysis by Keynes. History of Political Economy, 39(3), $529-543$.

Keynes, J. M. (1921). A Treatise on Probability. London, Macmillan.

John Maynard Keynes, (1973c). The General Theory of Employment, Interest and Money, Vol. 7 of the CWJMK, ed. by D. Moggridge. London: Macmillan.

Keynes, J.M. (1921). A Treatise on Probability. The Collected Writings of John Maynard Keynes, Vol. VIII. London: Macmillan, 1973.

J. M. Keynes (1937). The general theory of employment. Quarterly Journal of Economics, 51(2), 209-223.

Keynes, J.M. (1936). The General Theory of Employment, Interest and Money, Harcourt, Brace and World: New York.

John Maynard Keynes (1973). The General Theory and After, Part I: Preparation, (The Collected Writings of John Maynard Keynes, Volume XIII) Palgrave Macmillan: London.

John Maynard Keynes (1973). The General Theory and After: Defence and Development, Vol. 14 Palgrave Macmillan.

John Maynard Keynes (1979). The General Theory and After: A supplement, Vol. 29 (Collected works of Keynes) ed. by D. Moggridge. Palgrave Macmillan: London.

Neisser, Hans. (1936). Secondary Employment: Some comments on R.F. Kahn's Formula. Review of Economics and Statistics, 18(1) pp. 24-30. 
Neisser, Hans. (1936). Dr. Neisser on Secondary Employment: A rejoinder. Review of Economics and Statistics, 18(1), $147-148$

Robertson, D.(1936). Some Notes On Mr. Keynes' General Theory Of Employment. Quarterly Journal of Economics, 51(1), 168-191 .

Robinson, Joan. (1972). What has become of the Keynesian Revolution? In Joan Robinson. ( ed.). After Keynes. 1973 Papers presented to Section F (Economics) at the 1972 Annual Meeting of the British Association for the Advancement of Science.

Samuelson, P. (1963). D. H. Robertson (1890-1963). Quarterly Journal of Economics, 77(4), 517-536.

Samuelson, P. (1977). St. petersburg paradoxes: Defanged, dissected, and historically described. Journal of Economic Literature, 12, 24-55.

Schumpeter, J.A. (1954). History of Economic Analysis .Oxford University Press; England (2 ${ }^{\text {nd }}$ ed., 1996)

Shackle, G.L.S. (1951). Twenty Years on: A Survey of the theory of the Multiplier. Economic Journal, LXI, 241-260.

Trevithick, J.A. (1994). The monetary prerequisites for the multiplier: an adumbration of the crowding-out hypothesis. Cambridge Journal of Economics, 18, 77-90. 